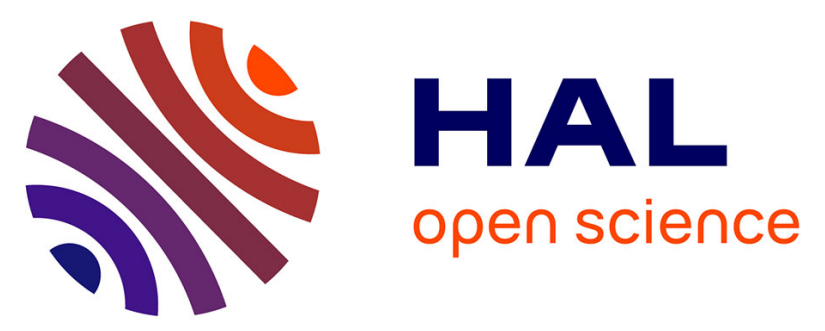

\title{
Experimental Validation of a Marine Current Turbine Simulator: Application to a Permanent Magnet Synchronous Generator-Based System Second-Order Sliding Mode Control
}

Seifeddine Benelghali, Mohamed Benbouzid, Jean Frédéric Charpentier, Tarek Ahmed-Ali, Iulian Munteanu

\section{To cite this version:}

Seifeddine Benelghali, Mohamed Benbouzid, Jean Frédéric Charpentier, Tarek Ahmed-Ali, Iulian Munteanu. Experimental Validation of a Marine Current Turbine Simulator: Application to a Permanent Magnet Synchronous Generator-Based System Second-Order Sliding Mode Control. IEEE Transactions on Industrial Electronics, 2011, 58 (1), pp.119-126. 10.1109/TIE.2010.2050293 . hal00564727

\section{HAL Id: hal-00564727 https://hal.science/hal-00564727}

Submitted on 9 Feb 2011

HAL is a multi-disciplinary open access archive for the deposit and dissemination of scientific research documents, whether they are published or not. The documents may come from teaching and research institutions in France or abroad, or from public or private research centers.
L'archive ouverte pluridisciplinaire HAL, est destinée au dépôt et à la diffusion de documents scientifiques de niveau recherche, publiés ou non, émanant des établissements d'enseignement et de recherche français ou étrangers, des laboratoires publics ou privés. 


\title{
Experimental Validation of a Marine Current Turbine Simulator: Application to a Permanent Magnet Synchronous Generator-Based System Second-Order Sliding Mode Control
}

\author{
Seifeddine Benelghali, Student Member, IEEE, Mohamed El Hachemi Benbouzid, Senior Member, IEEE, \\ Jean Frédéric Charpentier, Member, IEEE, Tarek Ahmed-Ali, and Iulian Munteanu, Member, IEEE
}

\begin{abstract}
This paper deals with the experimental validation of a Matlab-Simulink simulation tool of marine current turbine (MCT) systems. The developed simulator is intended to be used as a sizing and site evaluation tool for MCT installations. For that purpose, the simulator is evaluated within the context of speed control of a permanent magnet synchronous generatorbased (PMSG) MCT. To increase the generated power, and therefore the efficiency of an MCT, a nonlinear controller has been proposed. PMSG has been already considered for similar applications, particularly wind turbine systems using mainly PI controllers. However, such kinds of controllers do not adequately handle some of tidal resource characteristics such as turbulence and swell effects. Moreover, PMSG parameter variations should be accounted for. Therefore, a robust nonlinear control strategy, namely second-order sliding mode control, is proposed. The proposed control strategy is inserted in the simulator that accounts for the resource and the marine turbine models. Simulations using tidal current data from Raz de Sein (Brittany, France) and experiments on a $7.5-\mathrm{kW}$ real-time simulator are carried out for the validation of the simulator.
\end{abstract}

Index Terms-Marine current turbine (MCT), modeling, nonlinear control, permanent magnet synchronous generator (PMSG), second-order sliding mode (SOSM), simulation.

\section{NOMENCLATURE}

MCT Marine current turbine.

PMSG Permanent magnet synchronous generator.

MPPT Maximum power point tracking.

SOSM Second-order sliding mode.

SHOM French navy hydrographic and oceanographic service.

BEM Blade element momentum

$\rho \quad$ Fluid density.

A Cross-sectional area of the marine turbine.

$V_{\text {tide }} \quad$ Fluid speed.

$C_{p} \quad$ Power coefficient.

$C \quad$ Tide coefficient.

$V_{\mathrm{st}}\left(V_{\mathrm{nt}}\right) \quad$ Spring (neap) tide current speed.

$\lambda \quad$ Tip speed ratio.

$s,(r) \quad$ Stator (rotor) index.

$d, q \quad$ Synchronous reference frame index.

$V(I) \quad$ Voltage (current).

$P(Q) \quad$ Active (reactive) power.

$\phi \quad$ Flux.

$\phi_{f} \quad$ Permanent magnet flux.

$T_{\mathrm{em}}\left(T_{\mathrm{m}}\right)$ Electromagnetic torque (mechanical torque).

$R \quad$ PMSG resistance.

$L \quad$ PMSG inductance.

$\omega \quad$ Electrical angular speed.

$f \quad$ Viscous friction coefficient.

$J \quad$ Turbine rotor inertia.

$p \quad$ Pole pair number.

\section{INTRODUCTION}

Cedex 9, France (e-mail: seifeddine.ben_elghali@ecole-navale.fr).

M. E. H. Benbouzid is with the EA 4325 LBMS, University of Brest, 29238 Brest Cedex 3, France (e-mail: Mohamed.Benbouzid@univ-brest.fr).

J. F. Charpentier is with the French Naval Academy Research Institute (IRENav EA 3634), French Naval Academy, 29240 Brest Cedex 9, France (e-mail: jean-frederic.charpentier@ecole-navale.fr).

T. Ahmed-Ali is with the UMR CNRS 6072 GREYC, University of Caen, 14032 Caen Cedex, France (e-mail: Tarek.Ahmed-Ali@ greyc.ensicaen.fr).

I. Munteanu was with the Grenoble Electrical Engineering Laboratory (G2Elab), 38402 Grenoble Cedex 9, France. He is now with Dunărea de Jos University of Galați, 800008 Galați, Romania (e-mail: iulian.munteanu@ ugal.ro).

Color versions of one or more of the figures in this paper are available online at http://ieeexplore.iee.org.

Digital Object Identifier 10.1109/TIE.2010.2050293
HERE ARE basically two ways of generating electricity
from marine and tidal currents: 1) by building a tidal barrage across an estuary or a bay in high tide areas or 2) by extracting energy from free-flowing water (tidal kinetic energy). Within the last few decades, developers have shifted toward technologies that capture tidally driven coastal currents or tidal stream [1]. The astronomic nature of this resource makes it predictable, to within 98\% accuracy for decades, and independent of prevailing weather conditions. This predictability is critical to a successful integration of renewable energy 


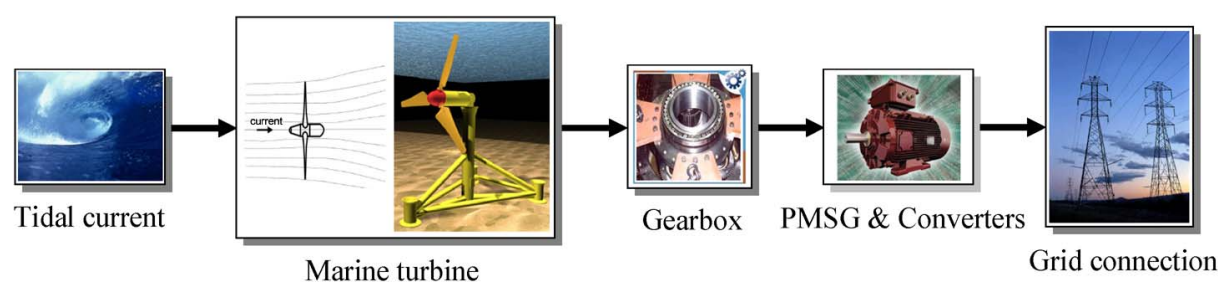

Fig. 1. Marine current turbine global block diagram.

in the electrical grid [2]. It is therefore obvious that there is a need to quantify the potential of generating electricity from these various sites [3].

This paper reports then on the experimental validation of a practical Matlab-Simulink simulation tool based on the modeling of the resource and the tidal turbine rotor. The BEM approach is in this case used for the turbine modeling.

In this paper, the simulator is evaluated within the context of the speed control of a permanent magnet synchronous generator (PMSG)-based marine current turbine (MCT). In previous works, different control strategies of control, mainly for doublyfed induction generator-based MCT, have been tested to evaluate the generated power [4]-[6]. In this paper, and in order to be able to compare and choose the adequate technology, a robust nonlinear control of a PMSG-based MCT is carried out [7], [8]. The adopted control strategy, namely second-order sliding mode (SOSM), relies on the resource and the marine turbine models that were validated by experimental data [9]. Simulations using tidal current data from Raz de Sein (Brittany, France) and experiments on a $7.5-\mathrm{kW}$ real-time simulator are carried out for validation purposes.

\section{Marine Current Turbine Modeling [9]}

The global scheme for a grid-connected MCT is given by Fig. 1 .

\section{A. Resource Model}

1) Resource Potential: The total kinetic power in an MCT has a similar dependence to that of a wind turbine and is governed by the following equation [10]:

$$
P=\frac{1}{2} \rho A V_{\text {tide }}^{3}
$$

However, a marine energy turbine can only harness a fraction of this power due to hydrodynamic behavior and (1) is modified as follows:

$$
P=\frac{1}{2} \rho C_{p} A V_{\text {tide }}^{3}
$$

For marine turbines, $C_{p}$ is estimated to be in the range $0.35-0.5$ [11].

2) Resource Model: Tidal current data are given by the SHOM and are available for various locations in chart form. The SHOM available charts give, for a specific site, the current velocities for spring and neap tides. These values are given at hourly intervals, starting at $6 \mathrm{~h}$ before high waters and ending

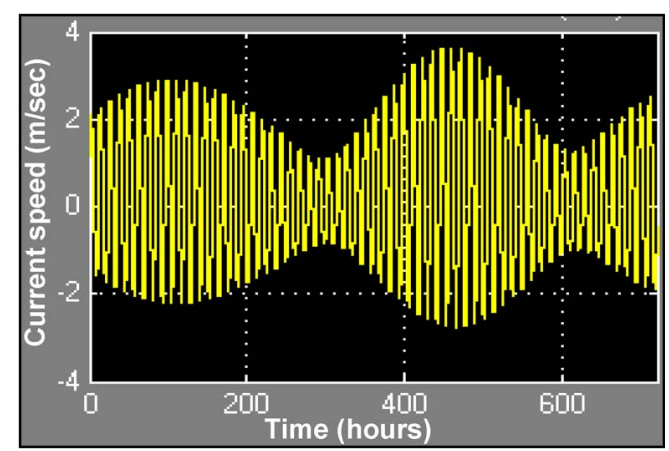

Fig. 2. Tidal velocity in Raz de Sein for March 2007.

$6 \mathrm{~h}$ after. Therefore, knowing tide coefficients, it is easy to derive a simple and practical model for tidal current speeds $V_{\text {tide }}$

$$
V_{\text {tide }}=V_{\mathrm{nt}}+\frac{(C-45)\left(V_{\mathrm{st}}-V_{\mathrm{nt}}\right)}{95-45}
$$

where $C$ is the tide coefficient which characterizes each tidal cycle (95 and 45 are, respectively, the spring and neap tide medium coefficient). This coefficient is determined by astronomic calculation of earth and moon positions. $V_{\mathrm{st}}$ and $V_{\mathrm{nt}}$ are, respectively, the spring and neap tide current velocities for hourly intervals starting at $6 \mathrm{~h}$ before high waters and ending $6 \mathrm{~h}$ after. For example, $3 \mathrm{~h}$ after the high tide in Brest, $V_{\mathrm{st}}=$ 1.8 knots and $V_{\text {nt }}=0.9$ knots. Therefore, for a tide coefficient $C=80, V_{\text {tide }}=1.53$ knots.

This first-order model is then used to calculate the tidal velocity each hour. The implemented model will allow the user to compute tidal velocities in a predefined time range. For illustration, Fig. 2 shows the model output for a month (March 2007). This adopted resource model has several advantages, including its modularity, not to mention its simplicity. Indeed, the marine turbine site can be changed, the useful current velocity can be adapted, and the time range taken into account can also be adapted from one month to one year.

\section{B. Turbine Rotor Model}

The harnessing of the energy in a tidal flow requires the conversion of kinetic energy in a moving fluid, in this case water, into the motion of a mechanical system, which can then drive an electrical generator. It is not too surprising, therefore, that many developers suggest using technology that mirrors that which has been successfully utilized to harness the wind, which is also a moving fluid [1]. Moreover, much of the technology is based upon the use of horizontal-axis turbines, such as that shown in Fig. 3. There are, however, a number of 


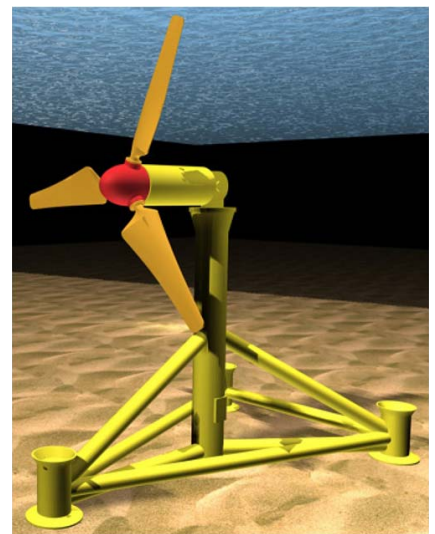

Fig. 3. Horizontal-axis tidal turbine.

fundamental differences in the design and operation of marine turbines. Particular differences entail changes in force loadings, immersion depth, different stall characteristics, and the possible occurrence of cavitations [12].

The BEM method has therefore been used for the marine turbine rotor modeling. Indeed, it is widely used in the industry as a computational tool to predict aerodynamic loads and power of turbine rotors [13].

It is relatively simple and computationally fast meeting the requirements of accuracy and control loop computational speed.

\section{PMSG Model}

The generator chosen for the marine current system was the PMSG [14]-[16]. Indeed, the benefit of using a PMSG in renewable energy applications as an alternative to conventional generators is its higher efficiency. Moreover, the elimination of the gearbox and the introduction of variable speed control would further increase the availability of the system, reducing its active weight and the need for maintenance. A schematic diagram of a PMSG-based generation system is shown in Fig. 4.

The PMSG dynamic equations are expressed in the $d-q$ reference frame. The model of electrical dynamics in terms of voltage and current can be given as (4) [17]

$$
\left\{\begin{array}{l}
V_{d}=R I_{d}+L_{d} \frac{d I_{d}}{d t}-\omega L_{q} I_{q} \\
V_{q}=R I_{q}+L_{q} \frac{d I_{q}}{d t}+\omega L_{q} I_{q}-\omega \phi_{f} .
\end{array}\right.
$$

The electromagnetic torque in the rotor is written as

$$
T_{\mathrm{em}}=\frac{3}{2} p\left[\left(L_{d}-L_{q}\right) I_{d} I_{q}-\phi_{f} I_{q}\right] .
$$

\section{Control of PMSG-Based MCT}

\section{A. Problem Formulation}

A common practice in addressing PMSG control problem is to use a linearization approach [15], [17]. However, due to the tidal resource characteristics such as turbulence and swell effects and the inevitable uncertainties inherent in PMSG-based marine current turbines, such control methods come at the price of poor system performance and low reliability [18]. Hence, there is the need for nonlinear and robust control to take into account these control problems.

Although many modern techniques can be used for this purpose, sliding mode control has proved to be particularly appropriate for nonlinear systems, presenting robust features with respect to system parameter uncertainties and external disturbances [19]-[22].

Sliding mode control copes with system uncertainty, keeping a properly chosen constraint by means of high-frequency control switching. Featuring robustness and high accuracy, the standard (first-order) sliding mode usage is, however, restricted due to the chattering effect caused by the control switching and the equality of the constraint relative degree to 1 . Higher order sliding mode approach (HOSM) suggests treating the chattering effect using a time derivative of control as a new control, thus integrating the switching [23], [24].

Up to now, a few SOSM control approaches have been introduced for wind and marine applications [4], [25], [26].

\section{B. Second-Order Sliding Mode Control Approach}

As the chattering phenomenon is the major drawback of practical implementation of sliding mode control, the most efficient way to cope with this problem is HOSM. This technique generalizes the basic sliding mode idea by acting on the higher order time derivatives of the sliding manifold, instead of influencing the first time derivative as it is the case in the standard (firstorder) sliding mode. This operational feature allows mitigating the chattering effect, keeping the main properties of the original approach [25].

The proposed control strategy is based on a step-by-step procedure.

1) First, the speed reference $\omega_{\text {ref }}$ is generated by an MPPT strategy [5].

2) Then, an optimal electromagnetic torque, which ensures the rotor speed convergence to $\omega_{\text {ref }}$, is computed using the following equation:

$$
T_{\text {em_ref }}=T_{\mathrm{m}}+f \omega-\alpha\left(\omega-\omega_{\text {ref }}\right)+J \dot{\omega}_{\text {ref }}
$$

where $\alpha$ is a positive constant. Afterwards, current references are derived to ensure the PMSG torque convergence to the optimal one

$$
\left\{\begin{array}{l}
I_{d \_ \text {ref }}=0 \\
I_{q_{-} \text {ref }}=\frac{2}{3} \frac{T_{\mathrm{em}}}{p \phi_{f}} .
\end{array}\right.
$$

To ensure currents convergence to their references, a SOSM strategy is used. Let us define the following sliding surfaces:

$$
\left\{\begin{array}{l}
S_{1}=I_{d}-I_{d \_ \text {ref }} \\
S_{2}=I_{q}-I_{q \_ \text {ref }} .
\end{array}\right.
$$

It follows that

$$
\begin{aligned}
& \left\{\begin{array}{l}
\dot{S}_{1}=\dot{I}_{d}-\dot{I}_{d \_ \text {ref }} \\
\ddot{S}_{1}=\varphi_{1}(t, x)+\gamma_{1}(t, x) \dot{V}_{d}
\end{array}\right. \\
& \left\{\begin{array}{l}
\dot{S}_{2}=\dot{I}_{q}-\dot{I}_{q \_ \text {ref }} \\
\ddot{S}_{2}=\varphi_{2}(t, x)+\gamma_{2}(t, x) \dot{V}_{q}
\end{array}\right.
\end{aligned}
$$




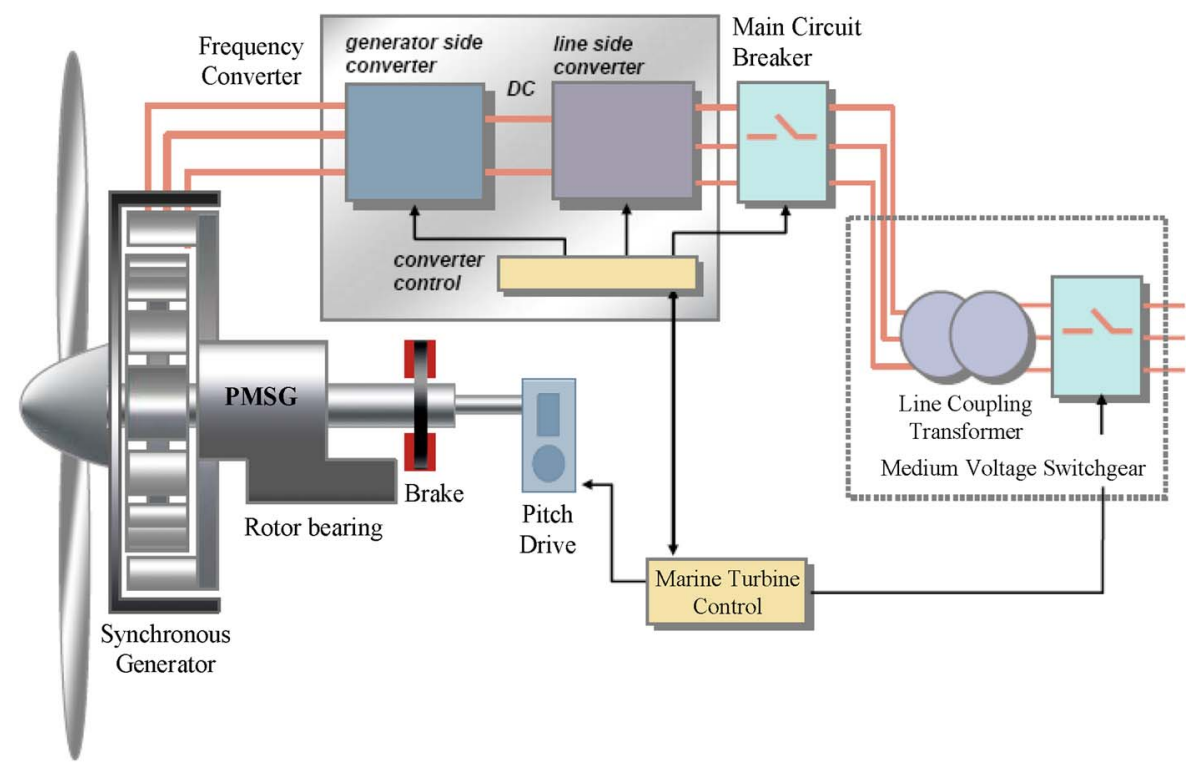

Fig. 4. Schematic diagram of a PMSG-based generation system.

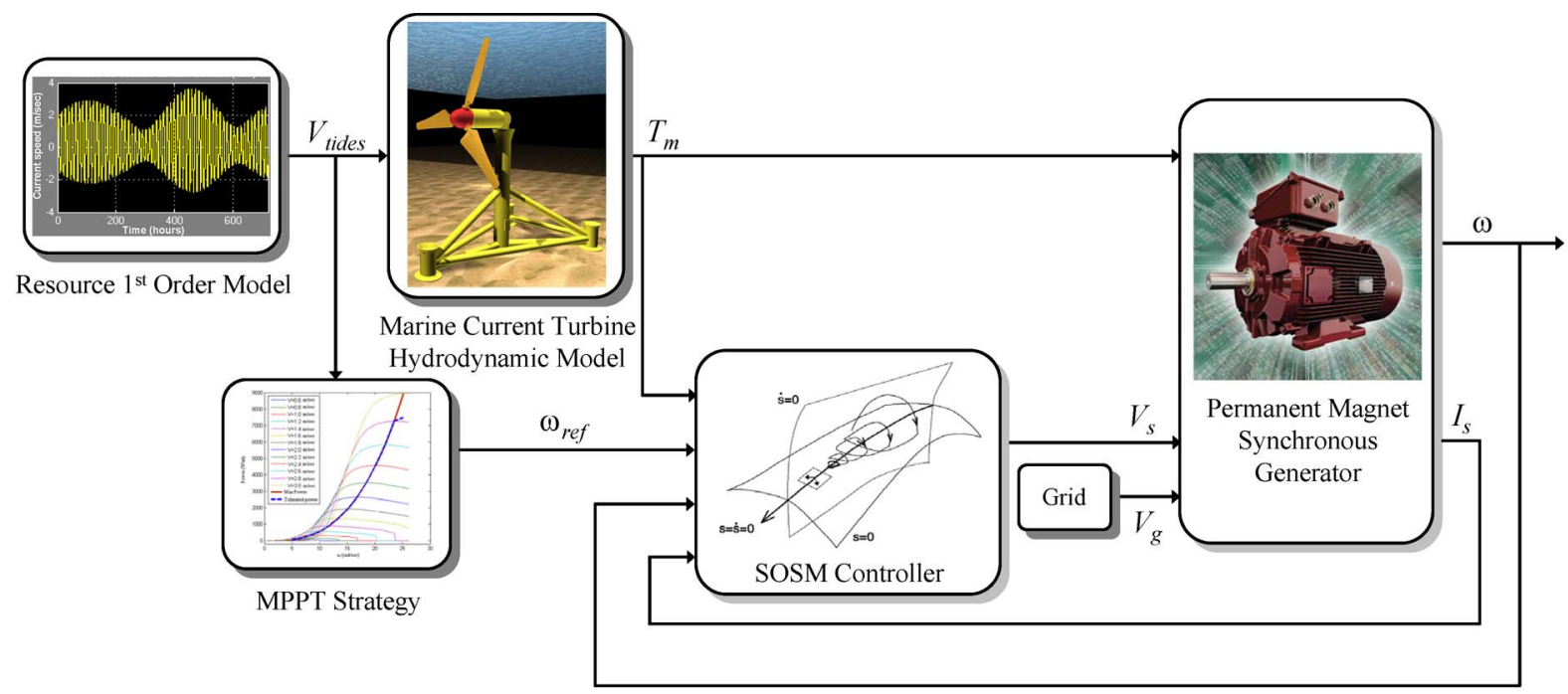

Fig. 5. Proposed control structure.

where $\varphi_{1}(t, x), \varphi_{2}(t, x), \gamma_{1}(t, x)$, and $\gamma_{2}(t, x)$ are uncertain where bounded functions that satisfy

$$
\begin{cases}\varphi_{1}>0,\left|\varphi_{1}\right|>\Phi_{1}, & 0<\Gamma_{m 1}<\gamma_{1}<\Gamma_{M 1} \\ \varphi_{2}>0,\left|\varphi_{2}\right|>\Phi_{2}, & 0<\Gamma_{m 2}<\gamma_{2}<\Gamma_{M 2}\end{cases}
$$

The main problem with HOSM algorithm implementations is the increased required information. Indeed, the implementation of an $n$ th-order controller requires the knowledge of $\dot{S}, \ddot{S}, \dddot{S}$, $\ldots, S^{(n-1)}$. The exception is the supertwisting algorithm, which only needs information about the sliding surface $S$ [23], [24]. Therefore, the proposed control approach has been designed using this algorithm. The proposed SOSM controller contains two parts

$$
\left\{\begin{array}{l}
V_{d}=u_{1}+u_{2} \\
V_{q}=w_{1}+w_{2}
\end{array}\right.
$$

In order to ensure the convergence of the sliding manifolds to zero in finite time, the gains can be chosen as follows [24]:

$$
\left\{\begin{array}{l}
\alpha_{i}>\frac{\Phi_{i}}{\Gamma_{m i}} \\
\beta_{i}^{2} \geq \frac{4 \Phi_{i}}{\Gamma_{m i}^{2}} \frac{\Gamma_{m i}\left(\alpha_{i}+\Phi_{i}\right)}{\Gamma_{m i}\left(\alpha_{i}-\Phi_{i}\right)} \\
0<\rho \leq 0.5
\end{array} \quad i=1,2 .\right.
$$

The above proposed SOSM control strategy for a PMSGbased MCT is illustrated by the block diagram in Fig. 5. 


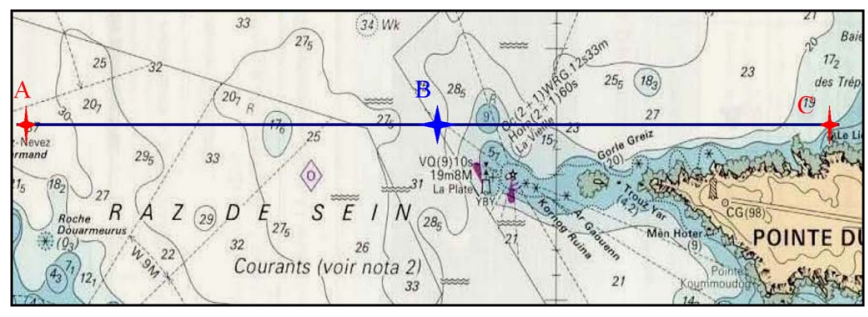

Fig. 6. Marine current turbine expected site of installation.

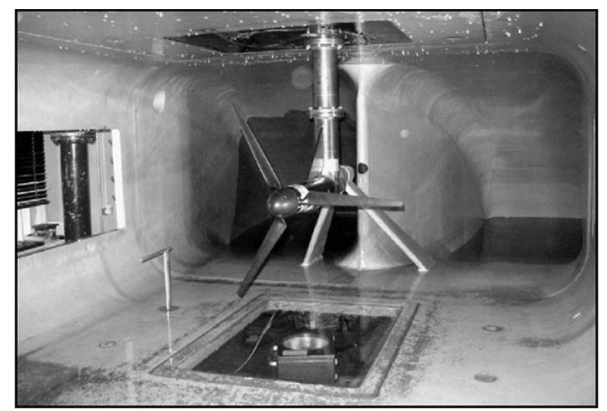

Fig. 7. Tested marine turbine [28].

Finally, and as an additional justification of such an advanced controller, it should be noted that its practical implementation implies an online computational cost similar to that of PI or PID controllers [25].

\section{VALIDATION RESULTS}

\section{A. Validation Using Developed Simulator}

1) Validation Data and Parameters: In this paper, the Raz de Sein site (Brittany, France) was chosen above several others listed in the European Commission report EUR16683 [27] due to the presence of high-speed current coupled with appropriate depths suitable for marine turbine.

Moreover, the marine current speed distribution for most of the time is greater than the minimum, estimated to be $1 \mathrm{~m} / \mathrm{s}$, required for economic deployment of marine turbine. The studied area is shown in Fig. 6, where A and C are the area ends and $\mathrm{B}$ the expected installation site for the marine current turbine.

The turbine rotor model was validated through the comparison of the simulation model with experimental data from the available literature [9] (Fig. 7). The adopted marine current turbine is of $1.44 \mathrm{~m}$ diameter rated at $7.5 \mathrm{~kW}$. For the given turbine geometry, the power for each rotor speed and a tidal current speed is determined by the BEM hydrodynamic model. In this context, the obtained power coefficient $C_{p}$ and the extractable power curves are shown in Fig. 8.

The 7.5-kW PMSG parameters are given in the Appendix.

2) Simulations: In this case, the MCT is simulated considering a resource first-order model (3). Therefore, for speed references given by Fig. 9 (MPPT) and a resource illustrated by Fig. 10, the PMSG-based MCT control performances are shown in Figs. 11-13, respectively, illustrating the current, the rotor speed, and the generated power. The obtained results show good

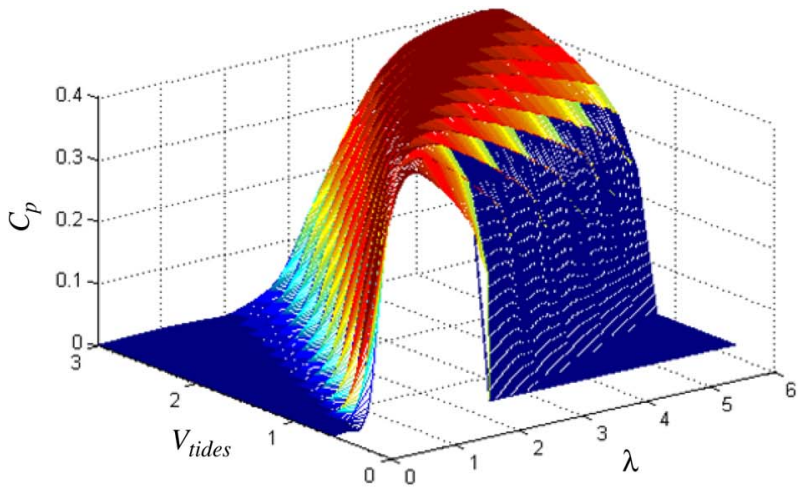

(a)

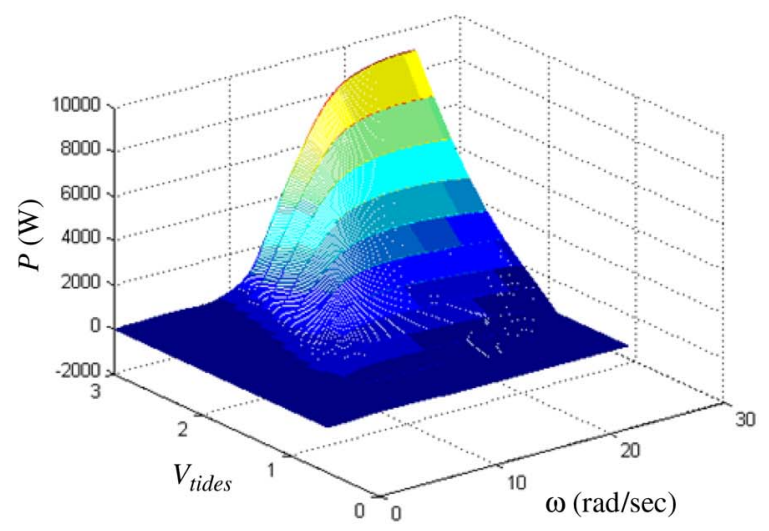

(b)

Fig. 8. Performances of the studied marine current turbine. (a) $C_{p}\left(\lambda, V_{\text {tides }}\right)$ curves. (b) The extractable power $P\left(\omega, V_{\text {tides }}\right)$.

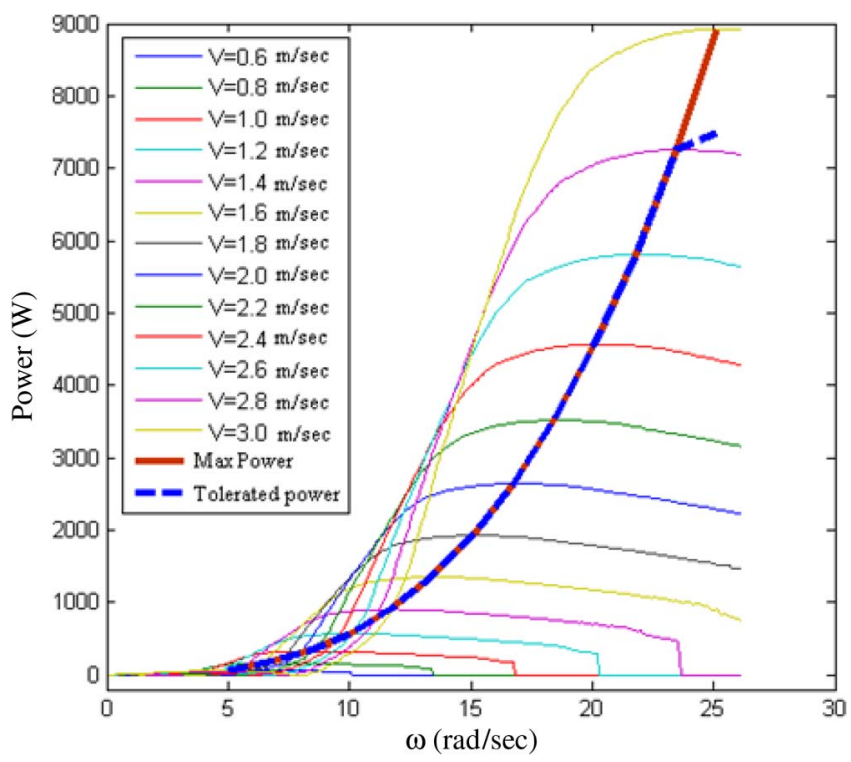

Fig. 9. Power curves for different tidal current speeds.

tracking performances of the PMSG current and rotor speed. Moreover, regarding [5] and as expected, the generated power is smoothest.

Figs. 11 and 13 exhibit a number of short peaks. These peaks are due to the Matlab-Simulink solver configuration and are not due to the PMSG-based MCT model. Indeed, 


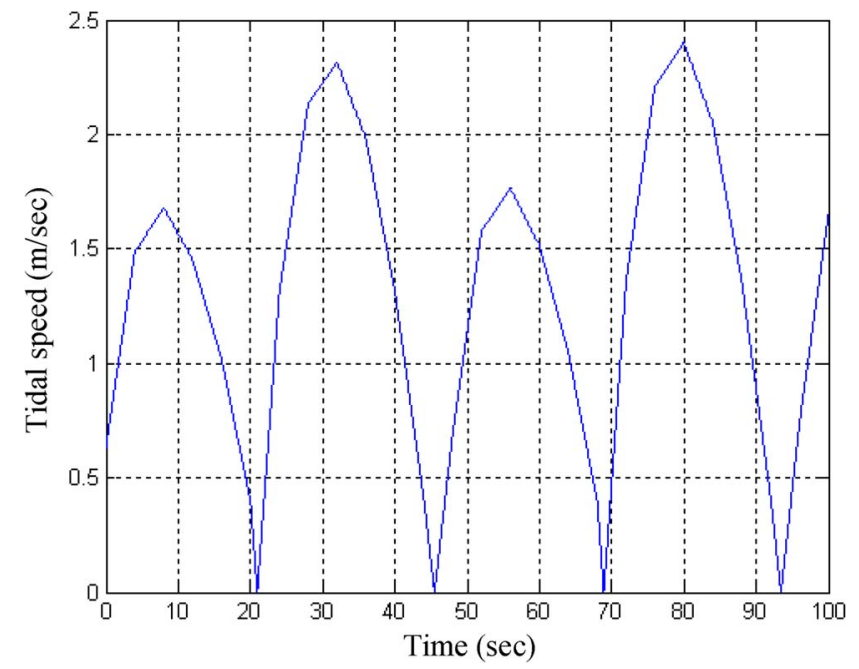

Fig. 10. Resource tidal speed.

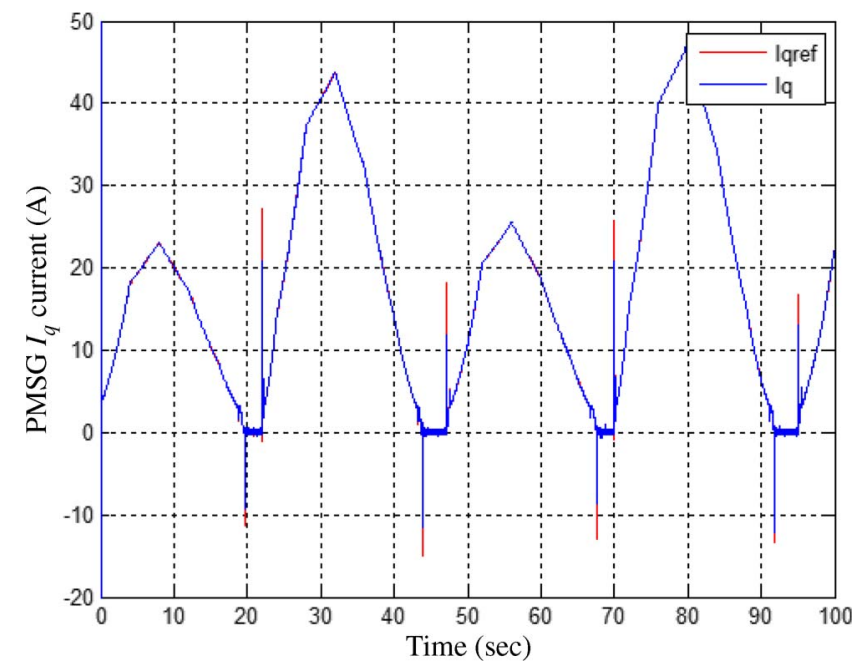

Fig. 11. PMSG $I_{q}$ current tracking performances.

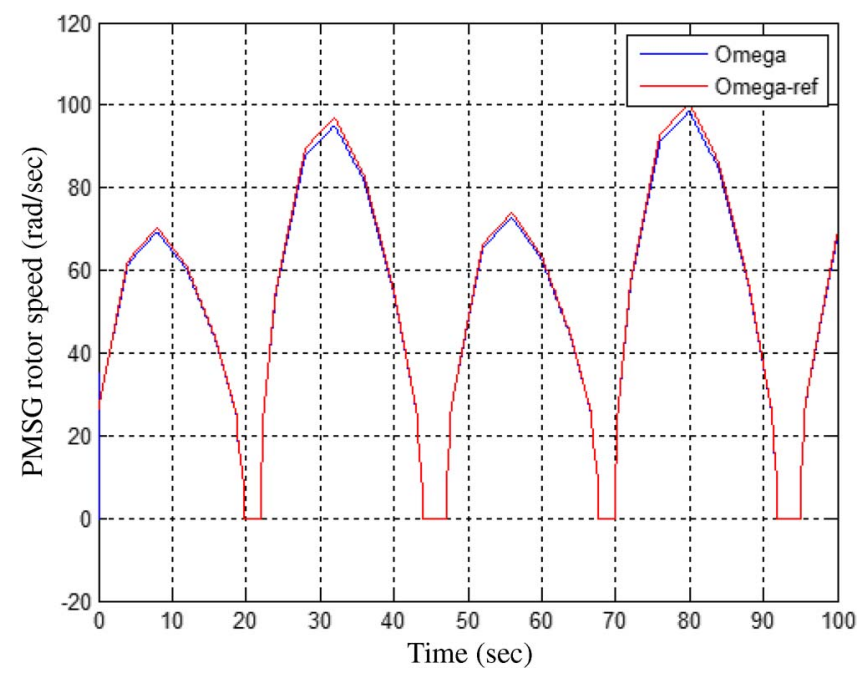

Fig. 12. PMSG rotor speed tracking performances.

by reducing the sampling time, those peaks will considerably decrease (even disappear), but the simulation time will greatly increase.

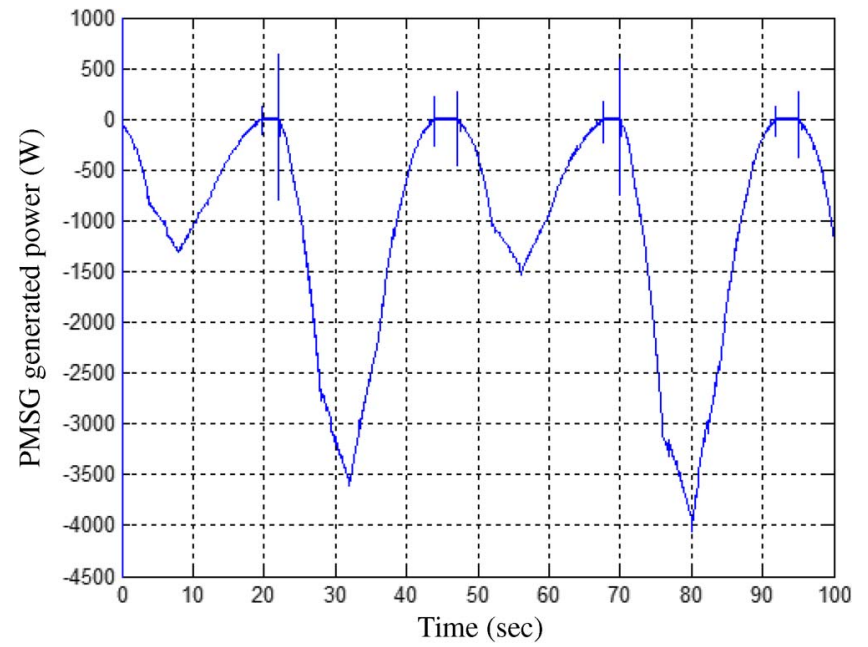

Fig. 13. PMSG generated power.

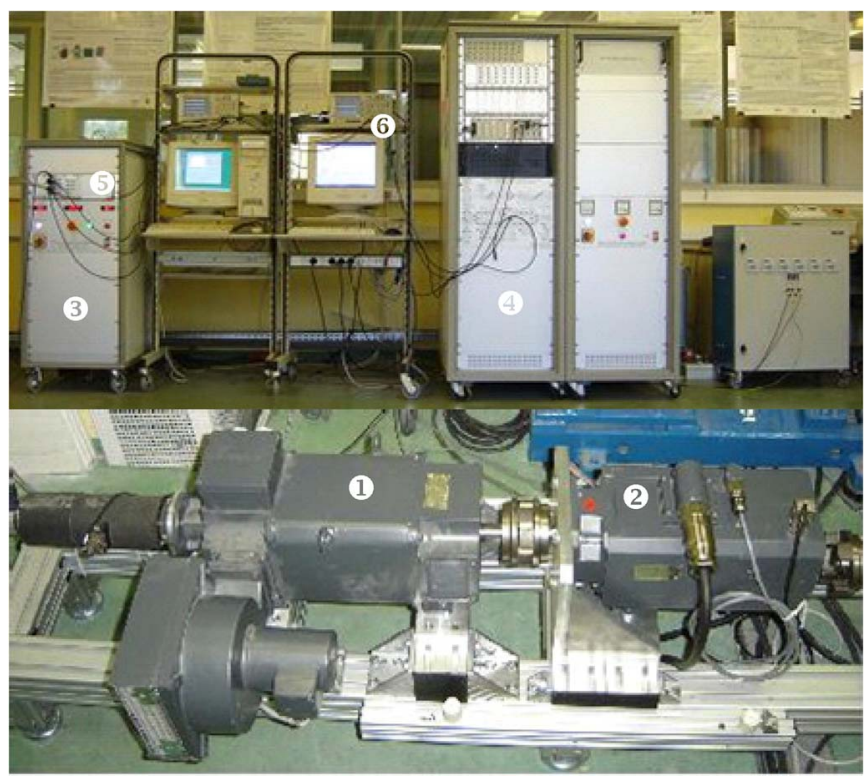

Fig. 14. Components of the G2Elab test bench, Grenoble, France: (1) dc motor, (2) PMSG, (3) Power electronics for driving the dc motor, (4) Power electronics for driving the PMSG, (5) DSP TMS320F240 implementing dc motor control, (6) DSP DS1005 (dSPACE) implementing PMSG-based MCT control.

Moreover, Figs. 11-13 have high peaks at $t=0$. These peaks are due to the initial value of the used integral blocs in MatlabSimulink. To overcome this problem in the experiments, the MCT connection to the PMSG has been delayed a few seconds.

\section{B. Experimental Tests}

For experimental validation of the proposed SOSM control approach, experiments were carried out using a renewable energy test bench built at the Grenoble Institute of Technology, France (G2Elab).

1) Test Bench [19]: The test bench presented in Fig. 14 allows the physical simulation of the marine power system. The MCT is emulated by a dc motor, which reproduces the torque and the inertia with respect to current tidal speeds and turbine 


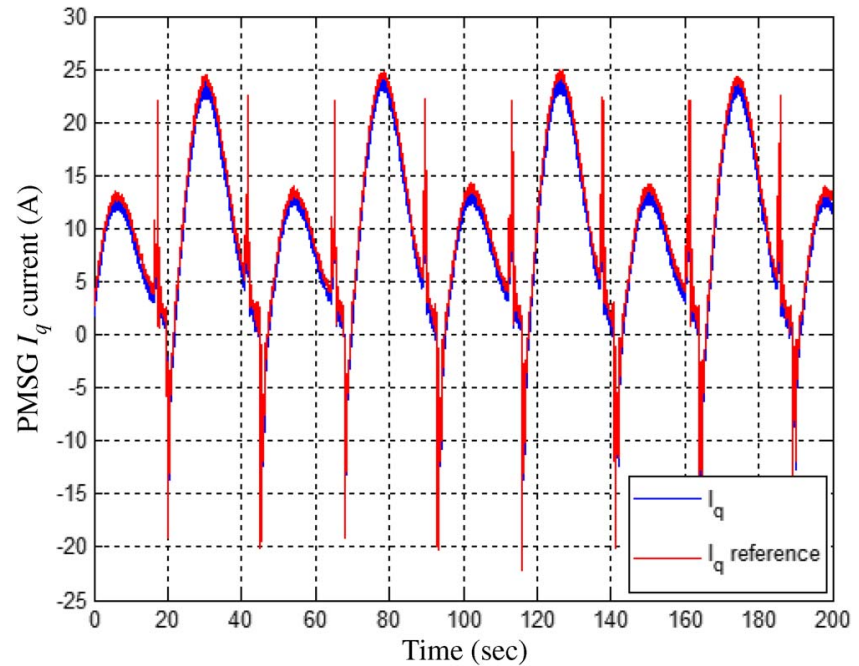

Fig. 15. Experimental PMSG $I_{q}$ current tracking performances.

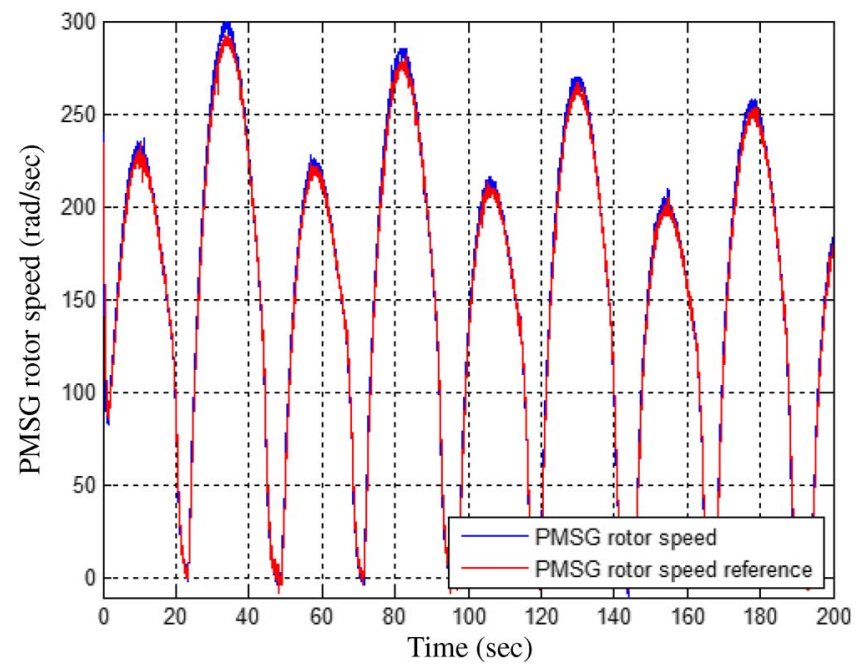

Fig. 16. Experimental PMSG rotor speed tracking performances.

rotational speed. The dc motor is coupled to a 7.5-kW PMSG (Appendix).

2) Experimental Tests: The experimental tests were carried out to be as close as possible to the simulation conditions for the MCT in Fig. 7. In these conditions, Figs. 15 and 16 show experimental control performances of the emulated PMSG-based MCT. These results show very good tracking performances in terms of the PMSG current and rotor speed.

For comparison purposes, Figs. 17 and 18 show simulation versus experimental results of the rotor speed and the generated power. Considering the real-world marine conditions, the obtained results are satisfactory. The test bench is equipped with current and torque limitations that explain some of Fig. 18 differences, in particular for high power generation.

Moreover, negative powers which transduce a motor behavior of the PMSG-based MCT can be enlightened by two main facts. The first one is that low tidal current speeds generate low torques, which, in certain cases, are able to lead the PMSG to the operating point imposed by the MPPT. The second one is the MCT acceleration that requires much more power to reach the targeted operating point.

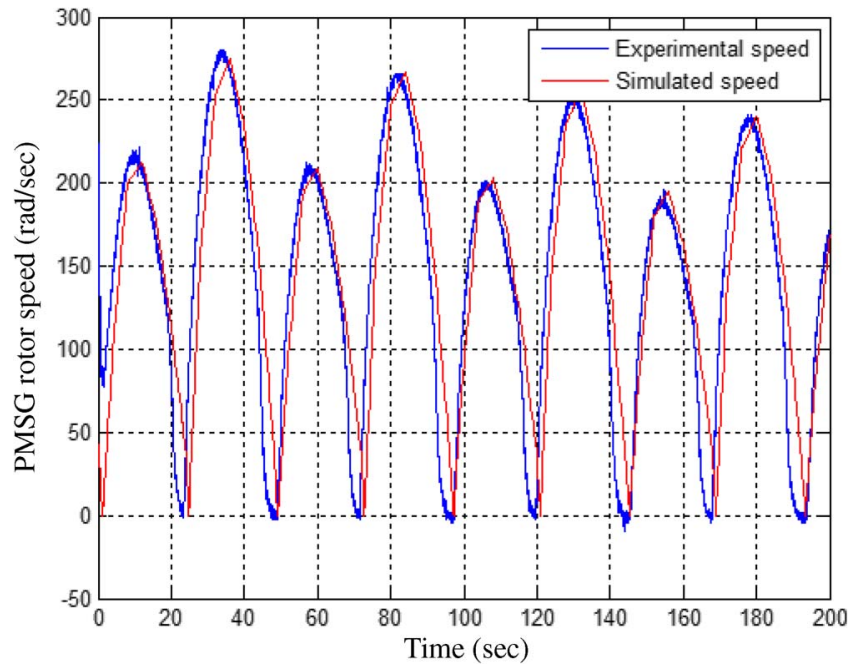

Fig. 17. Rotor speed: Experiments versus simulation.

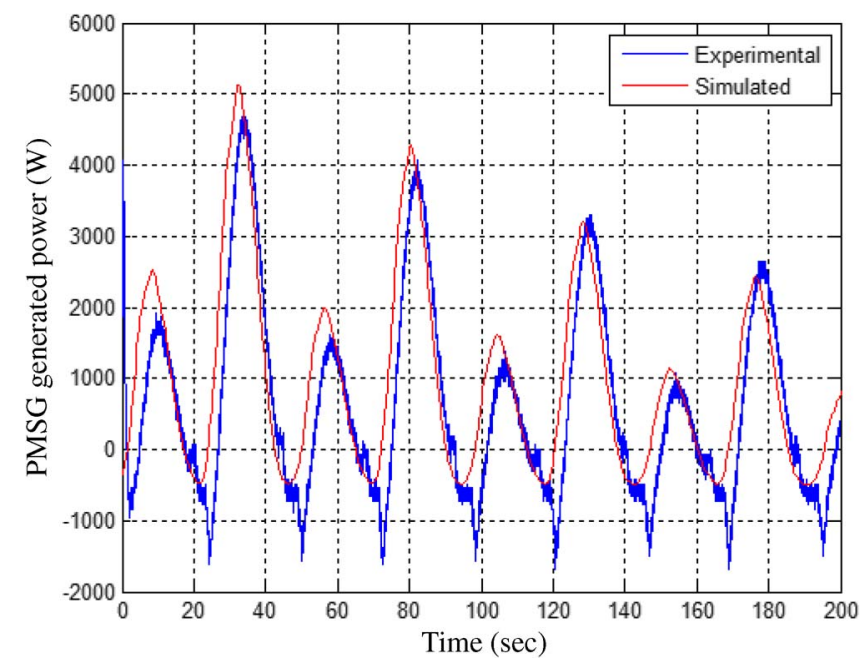

Fig. 18. Output power: Experiments versus simulation.

\section{CONCLUSiON}

This paper has dealt with the experimental validation of a Matlab-Simulink simulation tool of MCT systems. The simulator was evaluated within the context of speed control of a PMSG-based MCT. For that purpose, a SOSM approach has been proposed for the control of a PMSG-based MCT. The proposed control strategy relies on the resource and the marine turbine models. Its main features are a chattering-free behavior, a finite reaching time, and robustness with respect to external disturbances (e.g., grid) and unmodeled dynamics.

Tidal current data from Raz de Sein (Brittany, France) have been used to run simulations of a $7.5-\mathrm{kW}$ prototype over various flow regimes and experimental tests have been carried out on a $7.5-\mathrm{kW}$ real-time simulator. The obtained results are satisfactory and very encouraging regarding the validation of the MCT systems simulator.

As the developed simulator is intended to be used as a sizing and site evaluation tool for MCT installations, the subsequent work should focus on the experimental validation of the simulator for a doubly-fed induction generator-based MCT [4]. 
TABLE I

PARAMETERS OF SimUlated AND TESTED PMSG

\begin{tabular}{c}
$7.5 \mathrm{~kW}, 3000 \mathrm{rpm}, 22 \mathrm{Nm}$ \\
$R=0.173 \mathrm{~m} \Omega, L_{d}=0.085 \mathrm{mH}, L_{q}=0.951 \mathrm{mH}, \phi_{f}=0.112 \mathrm{~Wb}$ \\
$J=0.0048 \mathrm{~kg} \cdot \mathrm{m}^{2}, f=8.510^{-3} \mathrm{Nms}^{-1}$ \\
\hline
\end{tabular}

TABLE II

PARAMETERS OF DC MOTOR

$6.5 \mathrm{~kW}, 3850 \mathrm{rpm}, 310 \mathrm{~V}, 24.8 \mathrm{~A}$

$R_{S}=78 \Omega, R_{r}=0.78 \Omega, L_{r}=3.6 \mathrm{H}, J=0.02 \mathrm{~kg} \cdot \mathrm{m}^{2}$

This will allow the use of the simulator to compare generator technologies that best fit a specific marine site. Natural future works are mainly due to the MCT simulator configuration. Indeed, due to its modularity, numerous improvements should be promptly considered. The first one is to include vertical-axis turbine models. This will give opportunities to investigate some of the numerous projects available in the literature [1]. The second one is to include the grid-connection. This will initiate very interesting works on grid-connection constraints as at the moment there is no real-word feedback.

\section{APPENDIX}

\section{See Tables I and II.}

\section{ACKNOWLEDGMENT}

The authors would like to thank Prof. S. Bacha from the Grenoble Electrical Engineering Laboratory (G2Elab), Grenoble, France, for allowing the use of the G2Elab renewable energy experimental facilities.

\section{REFERENCES}

[1] S. Benelghali, M. E. H. Benbouzid, and J. F. Charpentier, "Marine tidal current electric power generation technology: State of the art and current status," in Proc. IEEE IEMDC, Antalya, Turkey, May 2007, vol. 2, pp. 1407-1412.

[2] P. Meisen and T. Hammons, "Harnessing the untapped energy potential of the oceans: Tidal, wave, currents and OTEC," in Proc. IEEE Power Eng. Soc. Gen. Meet. Panel Session, San Francisco, CA, Jun. 2005, pp. $1853-1854$.

[3] L. E. Myers and A. S. Bahaj, "Simulated electrical power potential harnessed by marine current turbine arrays in the Alderney Race," Renew. Energy, vol. 30, no. 11, pp. 1713-1731, Sep. 2005.

[4] S. Benelghali, M. E. H. Benbouzid, T. Ahmed-Ali, and J. F. Charpentier, "High-order sliding mode control of DFIG-based marine current turbine," in Proc. IEEE IECON, Orlando, FL, Nov. 2008, pp. 1228-1233.

[5] S. Benelghali, M. E. H. Benbouzid, and J. F. Charpentier, "Modeling and control of a marine current turbine driven doubly-fed induction generator," IET Renew. Power Gener, vol. 4, no. 1, pp. 1-11, Jan. 2010.

[6] J. W. Park, K. W. Lee, and H. J. Lee, "Wide speed operation of a doublyfed induction generator for tidal current energy," in Proc. IEEE IECON, Busan, South Korea, Nov. 2004, vol. 2, pp. 1333-1338.

[7] S. M. Abu Sharkh, D. Morris, S. R. Turnock, L. Myers, and A. S. Bahaj, "Performance of an integrated water turbine PM generator," in Proc. IEE PEMD, Bath, U.K., Apr. 2002, vol. 2, pp. 486-491.

[8] S. Benelghali, M. E. H. Benbouzid, J. F. Charpentier, T. Ahmed-Ali, and I. Munteanu, "High-order sliding mode control of a marine current turbine driven permanent magnet synchronous generator," in Proc. IEEE IEMDC, Miami, FL, May 2009, pp. 1541-1546.

[9] S. Benelghali, R. Balme, K. Le Saux, M. E. H. Benbouzid, J. F. Charpentier, and F. Hauville, "A simulation model for the evaluation of the electrical power potential harnessed by a marine current turbine," IEEE J. Ocean. Eng., vol. 32, no. 4, pp. 786-797, Oct. 2007.
[10] J. S. Couch and I. Bryden, "Tidal current energy extraction: Hydrodynamic resource characteristics," Proc. IMechE M, J. Eng. Marit. Environ., vol. 220, no. 4, pp. 185-194, 2006.

[11] L. E. Myers and A. S. Bahaj, "Power output performance characteristics of a horizontal axis marine current turbine," Renew. Energy, vol. 31, no. 2, pp. 197-208, Feb. 2006.

[12] W. M. J. Batten, A. S. Bahaj, A. F. Molland, and J. R. Chaplin, "Hydrodynamics of marine current turbines," Renew. Energy, vol. 31, no. 2, pp. 249-256, Feb. 2006.

[13] G. Mattarolo, P. Caselitz, and M. Geyler, "Modelling and simulation techniques applied to marine current turbine," in Proc. Int. Conf. Ocean Energy, Bremerhaven, Germany, 2006.

[14] J. F. Conroy and R. Watson, "Frequency response capability of full converter wind turbine generators in comparison to conventional generation," IEEE Trans. Power Syst., vol. 23, no. 2, pp. 649-656, May 2008.

[15] M. Chinchilla, S. Arnaltes, and J. C. Burgos, "Control of permanentmagnet generators applied to variable-speed wind-energy systems connected to the grid," IEEE Trans. Energy Convers., vol. 21, no. 1, pp. 130-135, Mar. 2006.

[16] J. M. Carrasco, L. G. Franquelo, J. T. Bialasiewicz, E. Galvan, R. C. P. Guisado, M. A. M. Prats, J. I. Leon, and N. Moreno-Alfonso, "Power-electronic systems for the grid integration of renewable energy sources: A survey," IEEE Trans. Ind. Electron., vol. 53, no. 4, pp. 1002 1016, Jun. 2006.

[17] K. Tan and S. Islam, "Optimum control strategies in energy conversion of PMSG wind turbine system without mechanical sensors," IEEE Trans. Energy Convers., vol. 19, no. 2, pp. 392-399, Jun. 2004.

[18] A. Mirecki, X. Roboam, and F. Richardeau, "Architecture complexity and energy efficiency of small wind turbines," IEEE Trans. Ind. Electron., vol. 54, no. 1, pp. 660-670, Feb. 2007.

[19] I. Munteanu, S. Bacha, A. Bratcu, J. Guiraud, and D. Roye, "Energyreliability optimization of wind energy conversion systems by sliding mode control," IEEE Trans. Energy Convers., vol. 23, no. 3, pp. 975-985, Sep. 2008.

[20] B. Beltran, T. Ahmed-Ali, and M. E. H. Benbouzid, "Sliding mode power control of variable-speed wind energy conversion systems," IEEE Trans. Energy Convers., vol. 23, no. 2, pp. 551-558, Jun. 2008.

[21] J. Matas, M. Castilla, J. M. Guerrero, L. Garcia de Vicuna, and J. Miret, "Feedback linearization of direct-drive synchronous wind-turbines via a sliding mode approach," IEEE Trans. Power Electron., vol. 23, no. 3, pp. 1093-1103, May 2008.

[22] F. Valenciaga and P. F. Puleston, "Variable structure control of a wind energy conversion system based on a brushless doubly fed reluctance generator," IEEE Trans. Energy Convers., vol. 22, no. 2, pp. 499-506, Jun. 2007.

[23] A. Levant and L. Alelishvili, "Integral high-order sliding modes," IEEE Trans. Autom. Control, vol. 52, no. 7, pp. 1278-1282, Jul. 2007.

[24] L. Fridman and A. Levant, "Higher order sliding modes," in Sliding Mode Control in Engineering. New York: Marcel Dekker, 2002, ch. 3, pp. 53-101.

[25] F. Valenciaga and P. F. Puleston, "High-order sliding control for a wind energy conversion system based on a permanent magnet synchronous generator," IEEE Trans. Energy Convers., vol. 23, no. 3, pp. 860-867, Sep. 2008.

[26] B. Beltran, T. Ahmed-Ali, and M. E. H. Benbouzid, "High-order sliding mode control of variable speed wind turbines," IEEE Trans. Ind. Electron., vol. 56, no. 9, pp. 3314-3321, Sep. 2009.

[27] "The exploitation of tidal marine currents," EU Commission, Brussels, Belgium, Rep. EUR16683EN, 1996.

[28] A. S. Bahaj, A. F. Molland, J. R. Chaplin, and W. M. J. Batten, "Power and thrust measurements of marine current turbines under various hydrodynamic flow conditions in a cavitation tunnel and a towing tank," Renew. Energy, vol. 32, no. 3, pp. 407-426, Mar. 2007.

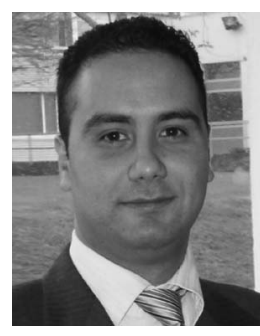

Seifeddine Benelghali (S'04) was born in Téboulba, Tunisia, in 1981. He received the B.Sc. degree in electrical engineering from ENIT, Tunis, Tunisia, in 2005, the M.Sc. degree in automatic control from the University of Poitiers, Poitiers, France, in 2006, and the $\mathrm{Ph} . \mathrm{D}$. degree in electrical engineering from the University of Brest, Brest, France, in 2009.

After receiving the Ph.D. degree, he joined the French Naval Academy, Brest, as a Teaching and Research Assistant. His current research interests include modeling and control of renewable energy 


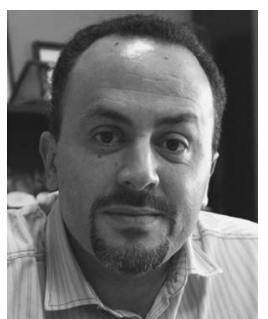

Mohamed El Hachemi Benbouzid (S'92-M'95SM'98) was born in Batna, Algeria, in 1968. He received the B.Sc. degree in electrical engineering from the University of Batna, Batna, Algeria, in 1990, the M.Sc. and Ph.D. degrees in electrical and computer engineering from the National Polytechnic Institute of Grenoble, Grenoble, France, in 1991 and 1994, respectively, and the Habilitation à Diriger des Recherches degree from the University of Picardie "Jules Verne," Amiens, France, in 2000.

After receiving the Ph.D. degree, he joined the Professional Institute of Amiens, University of Picardie "Jules Verne," where he was an Associate Professor of electrical and computer engineering. In September 2004, he joined the University Institute of Technology (IUT) of Brest, University of Brest, Brest, France, as a Professor of electrical engineering. His main research interests and experience include analysis, design, and control of electric machines, variable-speed drives for traction, propulsion, and renewable energy applications, and fault diagnosis of electric machines.

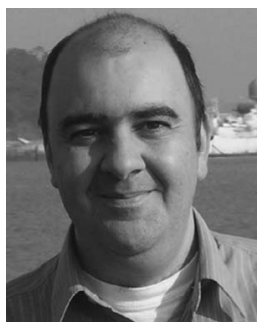

Jean Frédéric Charpentier (M'02) was born in Tananarive, Madagascar, in 1969. He received the M.Sc. and Ph.D. degrees in electrical engineering from the National Polytechnic Institute of Toulouse, Toulouse, France, in 1993 and 1996, respectively.

From 1996 to 1997, he was a Postdoctoral Fellow at Laval University, Quebec City, QC, Canada. From 1997 to 2002, he was an Assistant Professor at the University Institute of Technology (IUT) of Brest, University of Brest, Brest, France. Since 2002, he has been an Associate Professor in the French Naval Academy, Brest. His current research interests include design aspects of electrical machines and drives, electrical naval propulsion systems, and marine renewable energy.

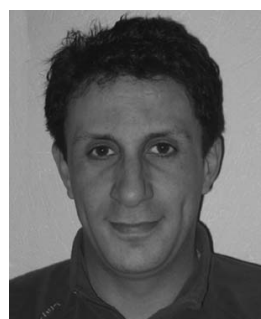

Tarek Ahmed-Ali was born in Algiers, Algeria, in 1972. He received the B.Sc. degree in electrical engineering from the Ecole Nationale Polytechnique of Algiers, Algiers, Algeria, in 1994, the M.Sc. degree in electrical and computer engineering from the University of Paris VI, Paris, France, in 1995, and the $\mathrm{Ph} . \mathrm{D}$. degree in electrical and computer engineering from the University of Paris Sud, Paris, in 1998.

In 1998, he joined the University of Paris XIII, Paris, as a Teaching and Research Assistant. In 1998, he moved to the Ecole Centrale de Lille, Lille, France, also as a Teaching and Research Assistant. In 2002, he was appointed to a lectureship in control engineering at Ecole Nationale des Ingénieurs des Etudes et Techniques de l'Armement of Brest (ENSIETA), Brest, France. In 2008, he was appointed Associate Professor of automatic control at the University of Caen, Caen, France. His main research interests are sliding mode control, nonlinear observers and fault-tolerant control and diagnosis in the field of ac drives.

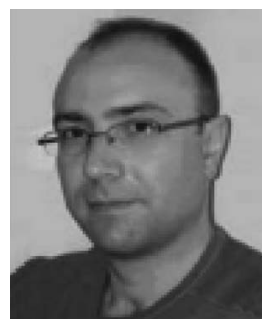

Iulian Munteanu (M'07) received the M.Sc. degree in instrumentation and control from the University of Le Havre, Le Havre, France, in 1997, and the Ph.D. degree in automatic control from the "Dunărea de Jos" University of Galați, Galați, Romania, in 2006.

In 2002, he was a Fellow of the Marie Curie European Framework Program at the Electrical Engineering Laboratory of Grenoble, Grenoble, France. $\mathrm{He}$ is currently with the Department of Electronics and Telecommunications, "Dunărea de Jos" University of Galați. His current research interests include optimal control of renewable energy systems. 